Articles

2009

\title{
Hot Off the Presses: Podcasting for the Economics Classroom
}

\section{Colleen Call}

Kathleen Owings Swan

University of Kentucky

Mark J. Hofer

College of William and Mary

Follow this and additional works at: https://scholarworks.wm.edu/articles

Part of the Economics Commons, and the Education Commons

\section{Recommended Citation}

Call, Colleen; Owings Swan, Kathleen; and Hofer, Mark J., "Hot Off the Presses: Podcasting for the Economics Classroom" (2009). Articles. 34.

https://scholarworks.wm.edu/articles/34

This Article is brought to you for free and open access by W\&M ScholarWorks. It has been accepted for inclusion in Articles by an authorized administrator of W\&M ScholarWorks. For more information, please contact scholarworks@wm.edu. 


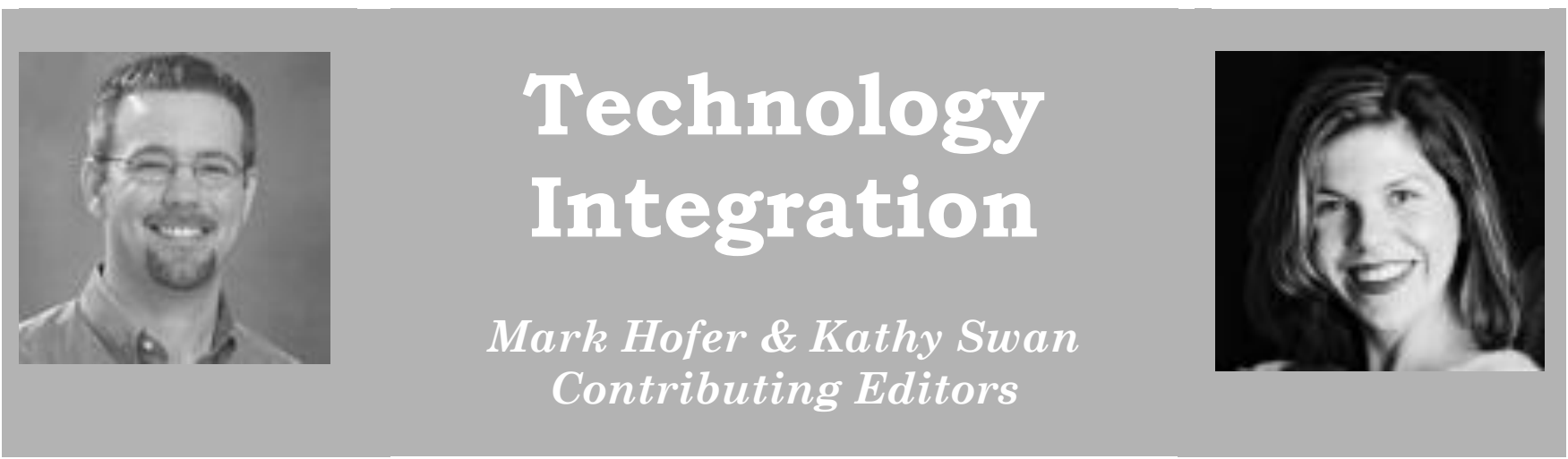

\section{Hot Off the Presses: Podcasting for the Economics Classroom}

Despite the recent interest and production of quality podcasts freely available online, there are relatively few podcasts available for $K-12$ teachers of economics. We see this as a missed opportunity given the real-time and real-world nature of economics. We have created the Econocast (http:/leconocast.org) website to help spark teachers' imaginations to leverage podcasting in the economics classroom and to help make the publication process easier. In this article, we offer a definition of podcasting, discuss how podcasting might support the economics curriculum, and present a case study of a teacher's development of an "iReport" economics podcast for her ninth grade classroom. We invite readers to help realize the potential of podcasting to engage students in meaningful learning of economics concepts.

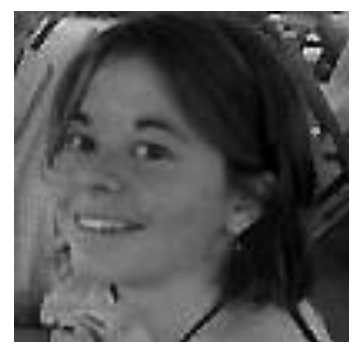

\section{Colleen Call}

Teaches in the social studies and International Baccalaureate program in a Kentucky public high school. A past recipient of the James Madison Memorial Fellowship. She served as AmeriCorps member and worked in designing and implementing a service-learning program for middle school students in the Boston area. This is her second year participating in the Econocast project.

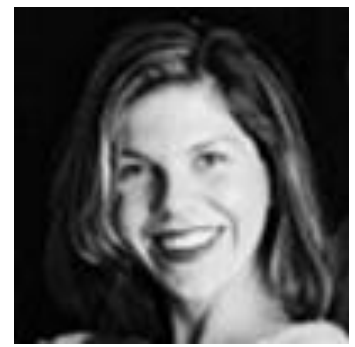

\section{Kathleen}

\section{Owings Swan}

Assistant professor of Curriculum \& Instruction, University of Kentucky School of Education. Former high school social studies teacher. Research includes examining strategies for training pre-service and in-service social studies teachers to effectively use educational technology in social studies instruction.

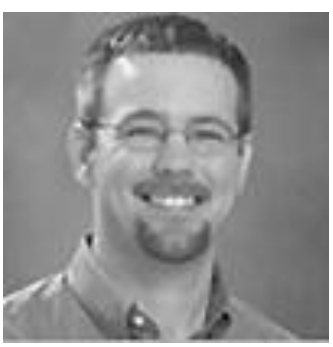

Mark Hofer

Associate professor of Educational Technology, The College of William \& Mary, School of Education. Former high school social studies teacher. Focuses on innovative ways to prepare pre-

service teachers to teaching and learning with the appropriate use of technology and on exploring K-12 classroom applications of technology.

Mailing Address: Curriculum \& Instruction, School of Education, The College of William and Mary, Williamsburg, VA

Email:mjhofe@wm.edu

\section{Article Citation (APA)}

Call, C., Swan, K. O., \& Hofer, M. (2009). Hot-off the presses: Podcasting for the economics classroom. Social Science Research \& Practice, 4 (2), 140-144. Retrieved [insert access date] from http://www.socstrp. org/issues/PDF/4.2.15.pdf 


\section{Economics and Podcasting}

In a recent article in the New York Times, former Federal Reserve vice chairman, Alan Binder (2009), argued that Americans made avoidable human errors on the path to the worst post-war recession in our nation's history. Six "whoppers," as he calls them, include a lack of regulation in the derivative and securities markets, an absence of regulatory foresight within the lending industry, and unwillingness on the part of our laissez faire government to step in when foreclosure rates began to rise and Lehman Brothers went belly up. The recessionary seal was affixed as the Troubled Asset Relief Program (TARP) mismanaged funds by injecting capital into banks instead of buying mortgage backed securities and commercial paper. Binder states, "Six fateful decisions - all made the wrong way. Imagine what the world would be like now if the housing bubble burst but those six things were different....." (2009, para. 12). As our financial futures loom precariously, now, more than ever, there is a strong case to be made that economics should be "front and center" in the K-12 social studies curriculum. From fiscal and monetary policy to Thomas Friedman's notion of a flattened world, students' abilities to read and understand the personal, micro, and macro-economic impact of the news has become paramount.

Print-based materials are increasingly available for educators to use in the classroom (e.g., the Wall Street Journal and the New York Times offer full online editions of their print editions). Several news sources, such as $N P R$ and The Economist, have recently turned to podcasting to disseminate information and commentary about today's global economy. For example, NPR's Marketplace and Marketplace Morning Report are produced daily, and these audio reports are available for download immediately after airing. While these audio podcasts can be useful resources for teachers trying to enhance students' economic thinking, they are not produced with the K-12 audience in mind. Often, the shows are thicketed with difficult terms - in fact, the senior producer, Paddy Hirsch, recently added a third installment called Marketplace Whiteboard for listeners who need some help "decoding" the financial meltdown in layman's terms. Included among the instructional segments are vodcasts (i.e., video podcasts) on credit default swaps and collateralized debt obligations. While useful for NPR's listeners, these podcasts are often above the heads of the typical K-12 student and intended for audiences steeped in economic news. Additionally, the passive nature of these podcasts-students listening and then perhaps discussing with a teacher - may not be in sync with more student-centered pedagogies that support effective teaching practice (Bransford, Brown, \& Cocking, 1999).

We see the dearth of economic podcasts produced for K-12 classrooms as a missed opportunity. Given the emphasis on connections to the real world and the fact that many economic concepts occur dynamically in real time, economics offers many opportunities for implementing instructional podcasting in engaging and effective ways. We suspect that the limited production of podcasting in economics is due primarily to two interconnected problems. First, teachers may not be aware of the full range of possible approaches to podcasting. Additionally, even if teachers have a vision for student- or teacher-generated podcasts, teachers may not know how to begin the production process. For these reasons, we have spent the last year developing and piloting the Econocast website. We envision the site as an evolving clearinghouse for diverse approaches to podcasting in the classroom with examples of innovative economics-oriented podcasts, a production process guide to assist with the recording and editing process and a means to host and share teacher- or student-generated podcasts. Economics teachers are able to request a free account and generate their own homepages that may include one or more podcasts. Users are able to configure and manage 


\section{Social Studies Research and Practice \\ http://www.socstrp.org}

their accounts online with little technical skill required. Our goal in developing the Econocast site was to minimize the technical barriers teachers may encounter so they may focus their valuable time and energy on what they do best - engaging their students in meaningful, substantive, and hands-on economics learning.

In this paper, we would like to introduce readers to the website with a short overview of its features and instructional possibilities. We also feature a classroom example of its use by inviting a classroom teacher to co-author the piece. Colleen Call shares her instructional context, Econocast curriculum, and the results from her project. Lastly, we invite readers to provide feedback and suggestions to the site as well as create their own podcasting projects.

\section{The Econocast Website}

We have developed the Econocast site to provide both a collection of economic podcasts for teachers to explore and a dedicated space to enable teachers to create their own podcast sites. For those wanting to browse existing podcasting projects, simply click on the "Consumer" tab on the website (see Figure 1). Finished projects can be searched by teacher name or by keyword.

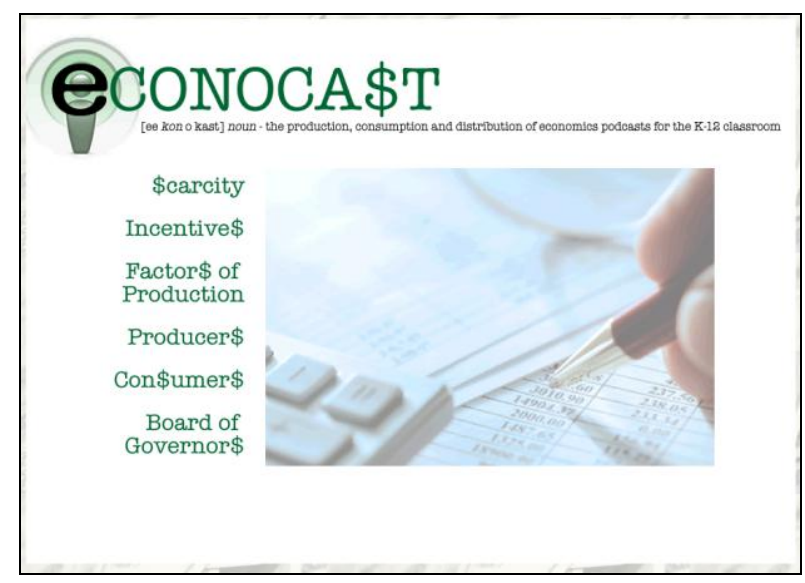

Figure 1. Screen shot of home page for web site.

Currently on the site, several projects have been developed. To view an Econocast project or to use samples in your classroom, click "View" on any one of the projects displayed (see Figure 2).

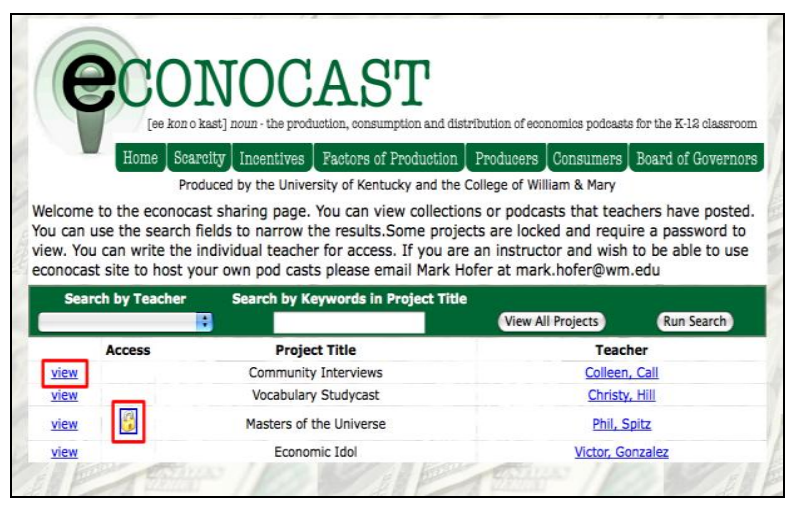

Figure 2. Screen shot of "Consumer" website page.

A lock symbol next to the project (see Figure 2 above) means that it is protected by a password. Available podcasts include a short description of the project and student podcasting samples as well as any ancillary materials used by the teacher.

In order to create their own Econocast podcast projects, teachers must request a user account for the site from the Producers page on the site. Once logged in, the teacher would click on the "Create/Manage Podcast" button (see Figure 3).

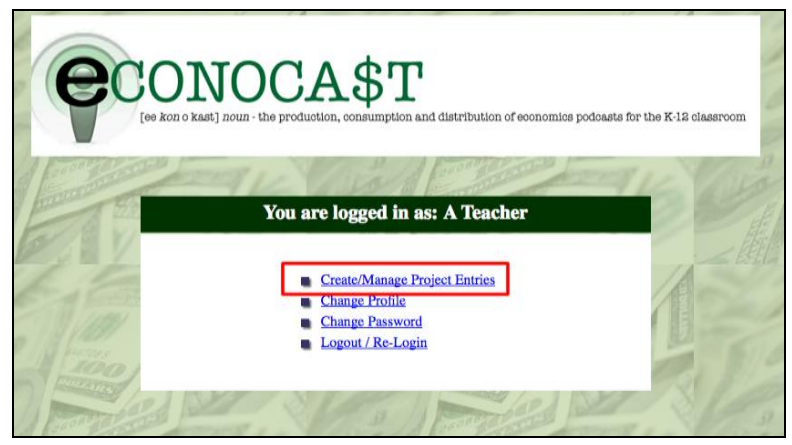

Figure 3. Create a podcast.

The creator then enters a title for the podcast and provides a brief description. By clicking 
on "Attach File to Project," the teacher can upload any handouts she provided the students as well as all the audio files for project. By clicking on the "Password Check" box, the teacher can password protect the published podcast (see Figure 4).

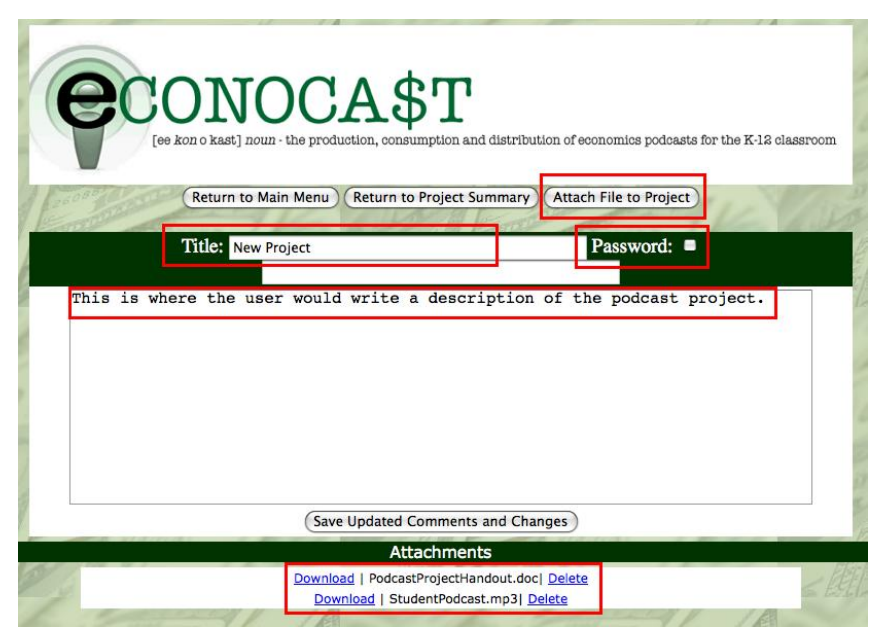

Figure 4. Podcast content.

\section{Featured Econocast Project}

Ms. Call teaches in the ninth-grade academy at a newly chartered International Baccalaureate (IB) suburban high school in a southeastern state. The IB diploma program is embedded within a rigorous state curriculum that is tested each spring. While Ms. Call teaches in a "non-accountability" year, she does feel administrative pressures and instructional constraints to get the scores up-no matter what the scores were the previous year or how high the gains were. The ninth-grade IB Economics course Ms. Call teaches actually covers the states standards for geography and civics as well as economics. The standards necessitate a fast-paced approach to content coverage with pacing guides and broad state standards guiding instruction.

While many teachers opt to "lecture through" the content, Ms. Call takes pedagogical risks by employing a variety of teaching strategies - in this case, podcasting projects in both academic years 2008 and 2009. The project occurred over eight instructional blocks (approximately 1.5 hours long) and in tandem with lessons on economic systems, monetary and fiscal policy, and demand and supply as well as global interdependence.

In 2008, Ms. Call was committed to the students doing economic fieldwork (or Ireports as she called them) and had the students investigate whether the national recessionary trends in 2008 were evident in the students' hometown of Lexington, Kentucky. At the time, it was not yet "official" that the United States was in a recession; however, many cities were seeing the signs of an economic downturn. The students began the project by selecting a person in the community to interview and then developing an interview protocol that focused on his or her impressions of the national economy as well as the local one. Additionally, students asked questions about the economy's impact on their particular occupation or business; for example, they asked questions such as the following: (a) Is your business looking to hire new employees in the upcoming months? and (b) Based on your experience, do you think Lexington is in a recession? Using their interview data as well as in-class readings and discussion, students then worked in their groups to create scripts from which they developed their I-Report-a journalist's report on the state of Lexington's economy. They took turns recording their podcasts using the software Garageband on Ms. Call's Macbook. Using the Econocast site, students accessed their classmates' reports for a culminating written assignment entitled "Is Lexington in a recession?" Call described the project this way:

From the initial interview that students conducted to the final stages in producing an Econocast, my students enjoyed great success. Economic terms and thinking took on real meaning. Students enjoyed the challenge of heading out into their community and conducting interviews related to the success and fail- 
ures of Lexington's economy. While some students came to the conclusion that we were in a recession, others determined that the conditions they observed did not show evidence of a recessionary economy. It was exciting to see ninth grade students take such ownership over the economic concept. I determined that the Econocast project was a curriculum "risk" worth taking. (Swan \& Hofer, 2009)

While many aspects of the projects went well, Ms. Call recognized the need for adaptations for the spring semester of the 2008-2009 academic school year. As a starting place, the question was no longer relevant. The official announcement that the United States was in a recession came in the fall of 2008-yes, Lexington $I S$ in a recession. For this year's project, Ms. Call focused on the business cycle - a theoretical diagram often difficult for students to grasp. In this year's project, students investigated whether Lexington had hit "rock bottom." In other words, what signs were there that Lexingtonians were coming out of the recession (a period of expansion), falling further into a depression (a period of contraction), or just plain stuck within an economic downturn.

Other changes to the project included more direct instruction on the production end of the podcasting projects. Call explained:

One shortcoming of my students' work from 2008 was their lack of confidence in telling the stories of Lexington's economy. Students lacked an appreciation for best practices of broadcasting. It became clear that this needed to be part of my overall instruction during the project.

Another change included exposing students to the recording technology in a civics unit-a "Votecast" project that occurred several months earlier. The Votecast project had stu- dents exploring whether voting was a responsibility, right, or duty by interviewing someone in their family about what makes a good citizen. This allowed students to practice with the technology before the assessed Econocast project in April.

In the following section, we invited Ms. Call to write about the project she conducted this spring at South Creek High School (pseudonym), finishing the week before this article was due to the editor-as such, we entitled the next section, "Hot off the Presses."

\section{Hot Off the Presses-Introducing Ms. Call}

Excited to begin the podcasting project, I introduced the concept to my students the first day of our economics unit. To help students see the link between the economics vocabulary discussed that day and the work we would take on with the Econocast project, I drew a graphic organizer of the business cycle on the board. Refreshing concepts just covered, students easily recounted the various points on the business cycle - growth, peak, contraction, trough, and recession. I stopped them at the term recession and posited the question, "How goes the Creek? Are our 'waters' rising, receding, or just dried up?" The expression on my students' faces was priceless. One student raised her hand and stubbornly asked, "Are you talking about our water fountains?" I realized then I needed to work on my sales pitch.

This student's question provides a window into the challenge of applying abstract concepts (i.e., demand, supply, recession, depression, business cycle) to real world of South Creek High School students (i.e., South Creek High School's basketball team, fundraisers, prom night). Throughout the Econocast project, I purposefully weaved in examples of how economic thinking can be applied to everyday situations. Economic indicators can range from a city's unemployment rate to a family's eating habits. Fiscal and monetary policy became the subject of economic comic books - the adventures of "Fiscal Policy Fred" 
allowed students to find creative outlets to apply economic thinking. Such exercises in the classroom allowed us to revisit the question of the podcast and helped the students understand that business cycles are not phenomenon for textbooks and Wall Street-our high school not only has its own cycle but is impacted by the national economic cycle.

The core of the students' podcasts needed to be an interview with a person who was part of the South Creek High School family. My students interviewed fellow students, their teachers, administrators, and members of the school's staff. This helped provide a range of responses from which students learned, depending on perspective, about the economic health of our school. Overall, the interviews went well. By keeping the subject of our interviews to South Creek High School, access was not a challenge for most of my students. We developed an interview protocol as a class. I provided a guideline of questions that students were required to ask; however, they had creative license to delve further.

It helped that students had the fall experience of the Votecast project under their belts, for the next step in the project was to turn their interviews into a working script. This concept was very difficult to teach in my first year with this project; however, students had the practice from the fall to help guide them toward a successful economic script. To guide them in this creation, I provided models of strong scripts. We also listened to various podcasts to determine what makes a good podcast. This helped students think about voice, inflection, and tone. The steps in creating a script proved to be a stepping stone to the final stage in the project - producing the podcast.

The production process was perhaps the most exciting part of the project stages. It is refreshing for a teacher to see students take so much ownership in their product. Despite a few technical glitches, the recordings were great successes. Students were prepared with their scripts and were familiar with the technology. To help with time constraints, I assigned student groups to various recording stations. Two stations were equipped with iMacs, and students used the program GarageBand to record. At the other four stations, students used digital recorders to produce their podcasts. Due to the fact that students had experience with GarageBand, but not digital recorders, the final products on GarageBand showed greater control of production elements. We were able to complete the recordings in one class block with only a few students needing extra time to polish their finished products.

To conclude the unit, I wanted students to have the opportunity to hear their classmates' recordings. I assigned students a writing prompt in which they were to answer the question presented to them at the beginning of the unit: "How goes the Creek?" As we listened to the podcasts, I pointed out various economic concepts students had uncovered throughout the course of the project. Discussion naturally flowed. Students finished the economics unit with a final product they had created by themselves. Ownership is critical in education-when students make connections between abstract concepts and the world they see, an authentic understanding is produced.

To view the students' projects and teacher materials, visit Econocast to listen to the NPResque projects the students created in both 2008 and 2009.

\section{Conclusion}

According to the Lenhart, Madden, Macgill, and Smith (2007), more than one half of the nation's teens engage in viewing, commenting upon, creating, and sharing multimedia content on the Web. Students express frustration that they do not often have these kinds of experiences in school (Levin \& Arafeh, 2002). Now that the tools required to do this kind of work are free and easily accessible, it has become technically possible for nearly any teacher to implement these kinds of projects in the classroom. And as Ms. Call demonstrates, 
even in a high-stakes testing environment, media content creation can be tied to and extend the core curriculum. To do so efficiently and effectively in economics, however, requires careful attention to scaffolding students' understandings of the many abstract concepts and their abilities to connect these to everyday life. This is clearly a challenging undertaking for teachers and requires them to take calculated risks and refine instruction based on experience. We hope that in sharing this project, teachers may gain practical tips on engaging students in both the theoretical components of economics as well using the technology in ways that advance their understanding. We invite other teachers to create and share their own projects and lessons learned. In this way, perhaps by pooling our collective experiences, we can help realize the potential of podcasting in the economics classroom.

\section{References}

Binder, A. (2009, January, 24). Six errors on the path to financial crisis. New York Times. Retrieved April 30, 2009, from http://www.nytimes.com/2009/01/25/business/econ omy/25view.html?_r=1\&em

Bransford, J., Brown, A., \& Cocking, R. (Eds.) (1999). How people learn: Brain, mind, experience, and school. Washington, DC: National Academy Press.

Lenhart, A., Madden, M., Macgill, A. R., \& Smith, A. (2007). Teens and social media. Retrieved April 30, 2009, from http://www.pewinternet.org

Levin, D., \& Arafeh, S. (2002). The digital disconnect: The widening gap between Internet savvy student and their schools. Washington, DC: Pew Internet \& American Life Project.

Swan, K. O., \& Hofer, M. (2009). Trend alert: A history teacher's guide to using podcasts in the classroom. Social Education, 73(2), 95-102.

Swan, K. O., \& Hofer, M. (in review). Econocast: The production, consumption and distribution of economics podcasts for the K-12 classroom. Social Education.

\section{Website}

\section{Econocast}

http://www.econocast.org 